\title{
FIRST RECORD OF PARAPERCIS OMMATURA (ACTINOPTERYGII: PERCIFORMES: PINGUIPEDIDAE) FROM THE INDIAN OCEAN
}

\author{
Dipanjan RAY ${ }^{1}$, Hsuan-Ching $\mathrm{HO}^{2}$, and Anil MOHAPATRA ${ }^{1 *}$ \\ ${ }^{1}$ Marine Aquarium and Regional Centre, Zoological Survey of India, Digha, India \\ ${ }^{2}$ National Museums of Marine Biology and Aquarium, Pingtung, Taiwan
}

Ray D., Ho H.-C., Mohapatra A. 2015. First record of Parapercis ommatura (Actinopterygii: Perciformes: Pinguipedidae) from the Indian Ocean. Acta Ichthyol. Piscat. 45 (4): 403- 405.

\begin{abstract}
This paper reports a finding of Parapercis ommatura Jordan et Snyder, 1902 from the Indian Ocean on the basis of detailed examination of 21 specimens collected from the West Bengal coast, on the northern part of Indian east coast. This species has previously been reported only from northwest Pacific regions. Detailed morphometric and meristic data for this species are provided.
\end{abstract}

Keywords: India, range extension, West Bengal, Bay of Bengal

The family Pinguipedidae is a group of marine fishes widespread in the Indo-Pacific region and Atlantic coast of South America and Africa, with about 7 genera and 87 valid species (Ho et al. 2014). Within this family, the genus Parapercis Bleeker, 1863 is the most abundant with 80 valid species (Ho et al. 2014). Species of Parapercis are generally small in size, near cylindrical anteriorly and compressed posteriorly, with the head and abdomen covered by ctenoid and/or cycloid scales. They are usually found on sandy or rubble bottom near coral reefs and sometimes on muddy substratum. These bottom dwelling fishes are carnivorous, and are regularly seen propped up by the ventral fins. Males are territorial and often maintain harems. Many species are reported to be protogynous hermaphrodites (Randall 2001).

During a local survey around the West Bengal coast of India, 21 fish specimens were collected and identified as Parapercis ommatura Jordan et Snyder, 1902, a species not previously known from the Indian Ocean. The species had previously been reported only from the northwest $\mathrm{Pa}-$ cific Ocean: Japan, Korea, China, Hong Kong (Cantwell 1964, Schultz 1968, Gomon 1980) and Vietnam (Prokofiev 2008). The purpose of the presently reported study was to provide detailed information on the first record of Parapercis ommatura from the Indian Ocean and to be more specific - from the coastal waters of India.

Twenty-one specimens of Parapercis ommatura (Standard length: 71.9-100.0 mm; Fig. 1) were collected from Digha Mohona and Shankarpur fishing ports of West Bengal, India. These two areas are respectively the largest fish market and the largest fishing harbour in West Bengal. Fishes were collected by trawl nets at a depth of 46-52 m.
After collection, the fish were promptly photographed and detailed measurements and counts were recorded following the methodology provided by Randall et al. (2008). The voucher specimens were deposited in the Museum of the Marine Aquarium and Regional Centre, Zoological Survey of India, Digha with Registration No: MARC/ZSI/ F3310. The abbreviations: SL and HL represent standard length and head length, respectively.

\section{Family PINGUIPEDIDAE Günther, 1860 Genus Parapercis Bleeker, 1863}

Parapercis ommatura Jordan et Snyder, 1902

Diagnosis. A species of Parapercis with single dark spot on upper caudal fin base; two stripes on cheek; scales rows below lateral line 12-13; outer row of lower jaw with eight canine teeth.

Description. Body elongated, cylindrical, and more compressed in caudal peduncle region. Body covered with ctenoid scales except snout and interorbital space. Head large, pointed with short snout; ventral part of head and chest flat. Eye large, rounded, located on dorsal part of head and slightly longer than snout; interorbital space narrow. Mouth moderately large, oblique with slightly projecting lower jaw; premaxilla protractile; maxilla reaching vertical from anterior part of eye. Jaws with two series of teeth, an outer row of curved, large canine like teeth and inner row of small teeth; palatine teeth absent; vomer with small patch of teeth. Eight recurved canine teeth on outer row at front of lower jaw. Posterior angle of opercle with sharp stout spine and 10-11 small spines on lower edge; preopercle with 6-7 small spines at angle. 


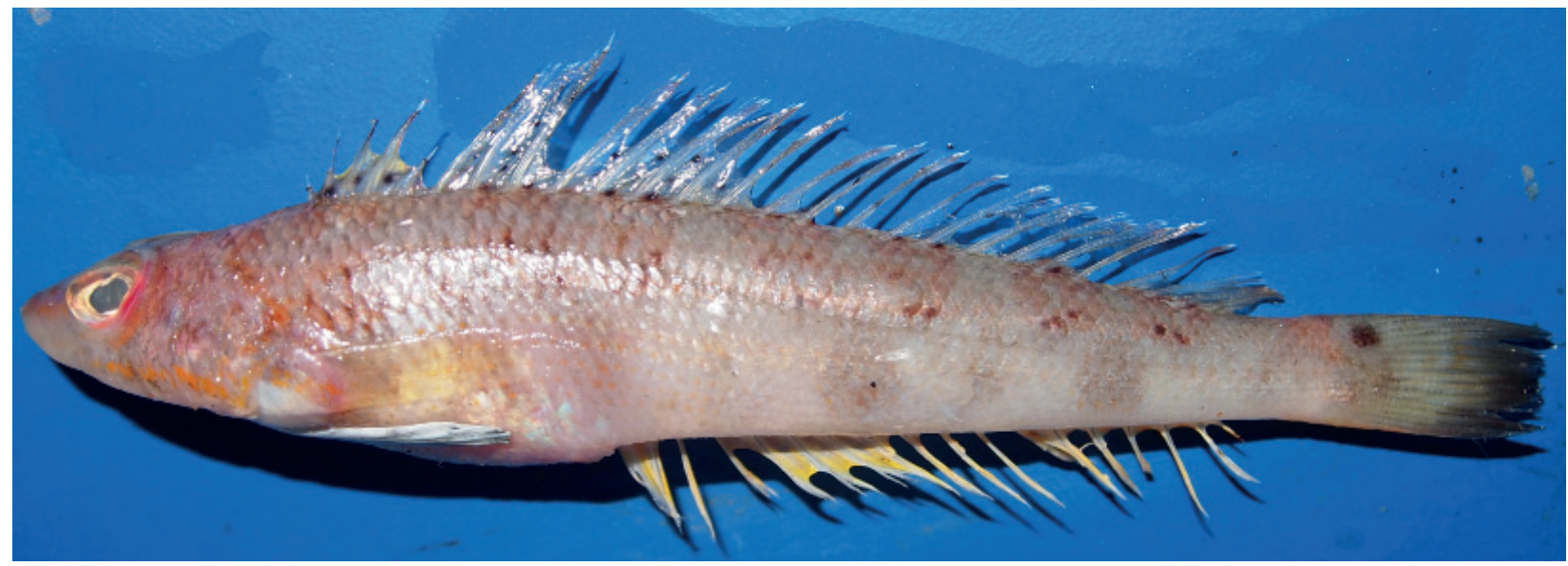

Fig. 1. Parapercis ommatura Jordan et Snyder, 1902, MARC/ZSI/F3310, a specimen collected in the Bay of Bengal $(\mathrm{SL}=93 \mathrm{~mm})$

Gill membrane connected to each other and forming fold across isthmus; gill rakers short, those on first arch: $3+$ 10-11 = 13-14. Fins: D: V, 22; A: I, 18; P: 14-15; V:I, 5; L1: 61-62. Spinous and soft-rayed portion of dorsal fin slightly joined at base, 4 th dorsal spine longest and strongest, rays higher than spines; Anal fin origin from just below 5th dorsal ray; posterior part of dorsal and anal fins ending equally; ventral fin pointed, almost reaching anus; pectoral fin acutely rounded and its tip reaching almost to anal fin origin; caudal fin rounded. Scales from dorsal fin origin to lateral line 4, scales from lateral line to anal opening 13; vertical cheek scales 6; scales around caudal peduncle 25-26; vertebrae: $10+19=29$. Morphometric measurements shown in Table 1.

Colour. Body light tan with three or four brownish ' $\mathrm{Y}$ ' shaped marks on sides; cheek with two narrow longitudinal dark bands; base of spinous dorsal partly dark, but otherwise white, soft dorsal membrane with 2-3 rows of dark elongate spots; anal fin light yellow, its margin dusky; middle of ventral fin black, base and tip white; pectoral fin pale yellow and base light brown; upper part of caudal fin with rounded black spot.

Remarks. Parapercis ommatura was first described from Nagasaki, Tsuruga, and Kobe in Japan. The original authors distinguished it from Parapercis pulchella (Temminck et Schlegel, 1843) on the basis of the caudal fin spot. However, P. ommatura is very similar to Parapercis diplospilus Gomon, 1981, described from Visayan Sea, Philippine Island, having similar dentition; 4th dorsal spine longest; last spine connected to 1st dorsal ray at base by a membrane; caudal vertebrae 19; and dorsal fin V, 22 . Both species also share a similar range of lateral line scales, scales above lateral line to dorsal fin origin and gill raker counts. However, P. ommatura differs from P. diplospilus by having no dark spot on lower caudal fin base (spot present on lower caudal fin base in P. diplospilus); scales below lateral line 12-13 (P. diplospilus 9-11); caudal fin rounded (truncate and upper rays of caudal fin slightly longer in $P$. diplospilus); 4th dorsal spine length 8.1\%-9.8\% SL (6.9\%$7.7 \%$ SL in P. diplospilus), and scales around caudal peduncle 25-26 (22-23 in P. diplospilus).
Table 1

Morphometric measurements of Parapercis ommatura

\begin{tabular}{|c|c|c|}
\hline Character & & Value \\
\hline Standard length & {$[\mathrm{mm}]$} & $71.9-100.0$ \\
\hline Body depth & \multirow{15}{*}{ 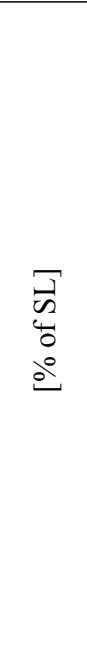 } & $15.3-16.5$ \\
\hline Head length & & $25.2-27.4$ \\
\hline Eye diameter & & $6.1-7.3$ \\
\hline Snout length & & $6.0-7.3$ \\
\hline Interorbital space & & $2.4-3.2$ \\
\hline Predorsal length & & $24.5-25.7$ \\
\hline Preanal length & & $42.0-43.4$ \\
\hline Dorsal fin base & & $63.5-64.5$ \\
\hline Anal fin base & & $47.7-49.1$ \\
\hline Pectoral fin & & $17.8-19.1$ \\
\hline Ventral fin & & $20.7-22.0$ \\
\hline Caudal fin & & $16.4-18.0$ \\
\hline Caudal peduncle depth & & $7.0-7.6$ \\
\hline 1st Dorsal fin & & $2.8-4.1$ \\
\hline 4th Dorsal fin & & $8.1-9.8$ \\
\hline Eye diameter & \multirow{5}{*}{ 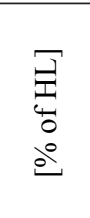 } & $24.3-26.2$ \\
\hline Snout length & & $19.9-21.2$ \\
\hline Interorbital space & & $8.9-10.0$ \\
\hline Upper jaw length & & $27.9-28.8$ \\
\hline Lower jaw length & & $29.9-32.3$ \\
\hline
\end{tabular}

$\mathrm{SL}=$ standard length, $\mathrm{HL}=$ head length.

A total of nine species of Parapercis have hitherto been reported from Indian coastal waters: Parapercis alboguttata (Günther, 1872); Parapercis clathrata Ogilby, 1910; Parapercis cylindrica (Bloch, 1972); Parapercis hexophtalma (Cuvier, 1829); Parapercis lineopunctata Randall 2003; Parapercis maculata (Bloch et Schneider, 1801); Parapercis millepunctata (Günther, 1860); Parapercis tetracantha (Lacepède, 1801); and Parapercis xanthozona (Bleeker, 1849). The presently reported study confirms the extension of the geographical range of Parapercis ommatura from the northwest Pacific to the Indian Ocean. 


\section{ACKNOWLEDGEMENTS}

The authors are thankful to Dr. K. Venkataraman, Director, Zoological Survey of India, Kolkata for providing the necessary facilities for this work. The first author (DR) is thankful to the Zoological Survey of India for the received Senior Research Fellowship.

\section{REFERENCES}

Cantwell G.E. 1964. A revision of the genus Parapercis, family Mugiloididae. Pacific Science 18 (3): 239-280.

Gomon J.R. 1981. Parapercis diplospilus (Pisces: Mugiloididae), a new species from the Philippine Islands. Proceedings of the Biological Society of Washington 93 (4): 989-996.

Ho H.C., Heemstra P.C., Imamura H. 2014. A new species of the sandperch genus Parapercis from the western Indian Ocean (Perciformes: Pinguipedidae). Zootaxa 3802 (3): 335-345.

DOI: $10.11646 /$ zootaxa.3802.3.3
Prokofiev A.M. 2008. Sandperches (Mugiloididae: Parapercis) of Nha Trang Bay, south China Sea, Vietnam. Journal of Ichthyology 48 (10): 876-890. DOI: $10.1134 / \mathrm{S} 0032945208100056$

Randall J.E. 2001. Pinguipedidae (Parapercidae, Mugiloididae). Sandperches. Pp. 3501-3510. In: Carpenter K.E., Niem V. (eds.) FAO species identification guide for fishery purposes. The living marine resources of the Western Central Pacific. Vol. 6. Bony fishes. Part 4 (Labridae to Latimeriidae) estuarine crocodiles. FAO, Rome.

Randall J.E., Senou H., Yoshino T. 2008. Three new pinguipedid fishes of the genus Parapercis from Japan. Bulletin of the National Museum of Natural Science Series A, Zoology 34 (Suppl. 2): 69-84.

Schultz L.P. 1968. Four new fishes of the genus Parapercis with notes on other species from the Indo-Pacific area (family Mugiloididae). Proceedings of the United States National Museum 124 (3636): 1-16. DOI: $10.5479 /$ si.00963801.124-3636.1

Received: 6 February 2015

Accepted: 14 April 2015

Published electronically: 31 December 2015 